\title{
IN SEARCH OF AN IDEAL ISLAMIC EDUCATION (The Contribution of Pesantren)
}

\author{
Oleh: M. Nur Kholis Setiawan ${ }^{*}$
}

Abstrak

Pesantren diakui banyak pengamat melabirkan sistem pendidikan yang menajamkan aspek affektiv dan psikbomotorik peserta didik dengan tidak meninggalkan aspek kognitif-nya. Sistem pendidikan nasional dinilai tidak banyak memberikan solusi bagi problem sosial di masyarakat Indonesia yang plural, tidak saja etnik, budaya, melainkan juga agama. Tulisan ini miengedepankan nilai-nilai masyarakat sipil, aivic values, yang diantaranya adalab, kebebasan, toleransi, demokrasi dan isu gender, yang sejatinya begitu lekat dalam sistem pendidikan pesantren. Terlepas dari kekurangan-kekurangan yang ada, pesantren tetap loyak untuk dijadikan sebagai penyumbang dalam pengembangan sistem pendidikan nasional yang asli dan mengedepankan moralitas serta sarat dengan nilai-nilai lubur.

يعترف كثير من المتخصصين بأن المناهج الدراسية التي تعمل بها في المعاهد التقليدية

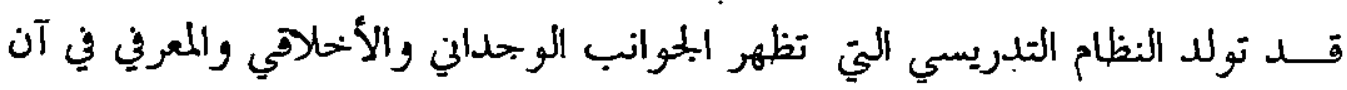
واحد. وقي الحين أن النظام الوطين اللتعليم قد عجزت لإيباد اللحلول للمشاكل التي لا تنفصـل طبيعــيا مع البحتمع الاندونيسي المتعلد الاثني والثقافي واللديني. وقدف الباحث إلى إبراز القيم المدنية التي تتضمن المرية بين الأفراد والتساهح والديكوقراطية وقضضـية البلنسانية التي تلون النظام التلريسي في المعاهد التقليدية. وبغض النظر عن

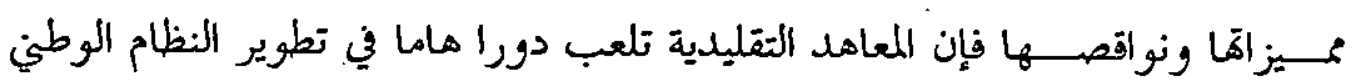
للتعليم التي تقدم الفضيلة الممثلئة بالقيم الصادقة.

Keywords: Islamic education, pesantren, nilai-nilai madani

* Graduated from Rheinische Friedrich Wilhelms Universität Bonn, Germany. Lecturer at the Postgraduate Program, State Islamic University Sunan Kalijaga, Executive Director of Dialogue Centre at the same Institution. Director of Mahad Ali, Wahid Hasyim Pesantren, Gaten, Yogyakarta. 


\section{A. Introduction}

Nicht nur Freiheit, sondern auch Gerechtigkeit

Nicht nur Gleichtigkeit sondern auch Pluralismus

Nicht nur Bruderschaft sondern auch Schwesterschaft

Nicbt nur Zusammenbleiben sondern auch Frieden.

(Not only freedom, but also justice, not only equality, but also plurality, not only brotherhood, but also sisterhood, not only co-existence, but also peace)

The above quotation of Hans Küng's global ethics is significant to think about an ideal type of education. Education, be it religious or secular one, that stresses the three important elements, namely cognitive, affective and psychomotoric ${ }^{2}$ are ideally practiced by everyone who gets an appropriate education. In a multi cultural context of Indonesian society, education should be directed to give to live awareness of the plurality in community. Cultural as well as religious aspects often cause social problems faced by Indonesian society in different region. In this respect, it is not surprising when many scholars have agreed that the tension among elements of society in Indonesia is still high whenever every single community does not have awareness of the importance of early warning system.

Such reality needs an alternative solution. The government policy on the national education system, which introduces some types of modification, is not sufficient in gaining the maximum goal of education. One indicator of the goal is the emergence of civic values such as freedom, tolerance, democratic, and pluralism. The lack of such values is due to among others a limited portion of moral and religious aspects in the curriculum. It makes educated people are morally and religiously not sufficient. In this respect, the national system of education needs additional elements, which originated from the local character of the nation that supports the ideal model of national education. One of them is the pesantren system of Islamic education.

Many Western and Indonesian scholars have conducted research on the pesantren from any different angles. The researchers are among others L.W.C. van den Berg who in the beginning of the nineteenth century studied pesantren from the perspective of mystical dimension. ${ }^{3}$ Karel Steenbrink's work was about the madrasab

'Hans Küng (2000), Global Etbits, München: Herder Verlag, p. 34.

2 On these terminologies, see Azyumardi Azra (2002), Paradigma Bara Pendidikan Nasional: Rekonstraksi dan Demokratisasi, Jakarta: Penerbit Kompas, pp. 180-181, see also Daniel Goleman (2005), Kecerdasan Emosional, trslt., T. Hermaya, Jakarta: Gramedia Pustaka Utama, pp. 5-17.

${ }^{3}$ See L.W.C. van den Berg (1886), "Heet Mohammedaansche Godsdientonderwijs op Java en Madoera en de Daarbij Gebruikte Arabische Boeken" in Tijdscbrift twor Indiscbe Taal, Land-en Volkenkende 31, pp. 519-555. 
education and pesantren in the $20^{\text {th }}$ century ${ }^{4}$ and Alois Müller's work was on the historical perspective of pesantren. ${ }^{5}$ Meanwhile, indigenous scholars are among others Zamakhsyari Dhofier, ${ }^{6}$ Dawam Raharjo, ${ }^{7}$ and the latest Abdurrahman Mas'ud. ${ }^{8}$ Despite the contribution these scholars make, their works have paid regrettably little attention to the moral and religious aspects that significantly support the civic values of the pesantren traditions. But, it does not necessarily mean that the previous researches made no valuable contribution to that matter.

The following article tries to focus on the elements of pesantren traditions that are still not sufficiently taken noticed of by scholars mentioned in the previous paragraph. Those elements are moral and educational which are characterized by the nature of brotherhood, neighbourhood, and other elements of civic values, such as freedom, tolerance, democracy and gender equality. It will answers a number of questions, i) what are the characteristic of pesantren education, ii) does pesantren contribute the ideal Islamic education, iii) how the civic values can be traced in the pesantren tradition.

\section{B. Pesantren and Local Wisdom}

Pesantren is the oldest institution for Islamic education in Indonesia and has been existed a long time before the independence of this country from the Dutch occupation. Almost all pesantren developed as a result of community initiatives. Thus, pesantren have a very strong basis in the community. Although they developed in line with the process of Islamization and use of Islamic symbols, pesantren are basically the cultural product of Indonesian origin.' Along with being Islamic educational institutions, which functions as centre of learning, pesantren have developed as socio-religious organizations, with direct influence over the establishment of social behaviours in the surrounding community, and are involved in the process of social change in Indonesia.

Over the last three decades pesantren have experienced rapid development in all aspects. Data from the Department of Religious Affairs shows that in 1977 there were 4195 pesantren, with approximately 677.384 students. This increased by 1981

${ }^{4}$ Karel Steenbrink (1994), Pesantren, Madrasab dan Sekolah:Pendidikan Islan dalam Kurun Moderen, Jakarta: LP3ES.

${ }^{5}$ Alois Müller (1996), Die Pesantren auf Jata, Frankfurt am Main.

'Zamakhsyari Dhofier (1982), Tradisi Pesantren, Jakarta: LP3ES.; dan Zamakhsyari Dhofier (1999), "The Pesantren Tradition: The Role of the Kyai in the Maintenance of Traditional Islam in Java Temple", Arizona State University Progran for Sostb East Asian Studies Monograph.

7 Dawam Raharjo (1985), Pergulatan Dumia Pesantren, Jakarta: LP3ES. LKiS.

s Abdurrahman Mas'ud (2004), Intelektual Pesantren: Perbelatan Agama dan Tradisi, Yogyakarta:

${ }^{9}$ Alois Mueller, Die Pesantren auf Java, p. 35. 
to approximately 5661 pesantren with 938.397 students. In 1985 the number of pesantren increased further, totalling 6239 with around 1.084.801 students. In 1997 the Department of Religious Affairs recorded 9388 pesantren with as many as 1.770.768 students and lately in 2001/2002 it is recorded that the number of pesantren is 12.783 with 2.974 .626 students. ${ }^{10}$ This total is still increasing with the establishment of new pesantren. Those pesantren can be roughly categorized into three models, classical, semi-classical and modern. This categorization is not based on a historical aspect, but merely on the method of learning. The first is mostly recognized by the classical curriculum without a formal school or education system acknowledged by the government, meanwhile the second is a half combination, and the third is adopting modern ways of religious learning including the use of foreign language such as English and Arabic in the daily life of the students.

The three types of pesantren are contributing different out put of students. The first type is directed mostly to purely religious knowledge and teaching. The knowledge is not received by student as a pure knowledge, but as the guidance and source for religious life. In other words, religious knowledge is being taken for granted by most students in this type of pesantren. The output is to some extent positive. The positive one can be seen in the attitude of students in worship, social interaction with their teachers and society. Student-teacher relation in the pesantren tradition is unique compared to that of in student-teacher relation in secular schools. Students in pesantren feel that obedience to the teacher's command in a good thing is an obligatory. This makes easier for teachers in control student's morality and religiosity. At the same time, the control mechanism in the pesantren tradition is more effective than that of normal and secular schools."

To adore a teacher in Islamic learning tradition in pesantren is part of getting the irsyâd al-ustâdz in the pursuit of the master's guidance. Alî ibn Abî Tâlib's poems that had been very popular in the pesantren community legitimise this part of the requirement of seeking knowledge: "The pursuit of knowledge is not carried on without six things which I shall indicate to you through words that are clear, ingenious acumen, fervent desire, patience, sufficient sustenance, the guidance of a teacher, and length of time". ${ }^{12}$ In this respect, the irsyad is not limited to during the lifetime of the teachers, but also continues after their death. They consider that useful knowledge is etemal. This is also supported by the utterance of the Prophet, "whenever person dies, his deeds are over, except for three things: perpetual charity, useful knowledge or a good child who makes supplications for his (deceased)

to Departemen Agama (2002), "Statistik Pondok Pesantren 2002”, Direktorat Pendidikan Keagamaan dan Pondok Pesantren, p. iii.

${ }^{11}$ Detailed account on this type of pesantren can be found in Zamakhsyari's book Tradisi Pesantren, especially pp. 56-74, 
parents. $^{13}$

Meanwhile, the second type of pesantren, which is a half combination between old model and new model, contributes both the morality and rationality. What is meant by old model is the curriculum, which concentrates on the classical books, which are called kitab kuning, without any modification. The new model is a set of curriculum, which adopts literature on Islamic studies that are contemporarily. In relation to the output of this type of pesantren, morality is here meant the same milieu found in the first category of pesantren with additional positive values. Rationality is one medium in understanding and interpreting religious texts with criticism. In this sense, teligious knowledge is received and perceived by them with the help of humanities and social sciences. This is because the contemporary literatures are being read in the second type of pesantren. The pesantren that belong to this group have no allergy in introducing a curriculum and sources of literature that are not merely classical but also modern one.

The third type is an exemplification of an ideal model of Islamic education due to its openness to renewal, tajdid, and its capability to adjust with modernity. Religious teaching, which takes religiosity and morality as a priority in the practice, is combined with the rationality and is developed in line with the progress of human knowledge. Perhaps this third type of pesantren is the most adaptable and adjustable to the development of Erkenntnistheorie in the sense of understanding religion within the framework of humanity. In other words, this type of pesantren is able to open themselves up to new concepts, ideas and systems by creating a compromise between the traditional and modern curriculum. It is needed to do so, otherwise the lack of resources and expertise due to the separation between traditional and modern one has become an obstacle for pesantren in providing an integrated and sound education for the community. ${ }^{14}$

Pesantren is also the source for community leaders, both local and national. Research shows that Indonesians still consider religion to be something important in their lives: $95,6 \%$ of them believe that religion gives them guidance, $95,9 \%$ come to ustadz or kyai (religious leader and teachers) to ask for advice and $94,6 \%$ trust what the ustadz says. Religious leaders, together with the institutions to which they belong, are highly respected by Indonesians. ${ }^{15}$

12

الال لا تالل العلم الا بسنة، سأنيك عن بمموعها بيان ذكاء ومرص وامطبار وبالنغة وارئاد أستاذ وطول زمان See al-Zarnûbî, Ta lim al-Muta allim, Semarang: Pustaka Alawiyah, p. 15

${ }^{13}$ This Propher's utterance is reported by Muslim and much used by Sunni. See Sya'rani Ahmadi (1986), al-Farấtid al-Saniyyab, Kudus: Menara Kudus, p.15.

${ }^{14}$ See Steenbrink (1994), op. cit., pp. 34-40. 2004.

${ }^{15}$ Unpublished research conducted by PPIM State Islamic Universiry Syarif Hidayatullah Jakarta, 
Someone has to bear in mind that these three types of pesantren still have more or less the same character. Among them is the local wisdom that perpetuates local cultures. The long history of perpetuating local culture in the context of Islamization the Archipelago can be traced in the role of saint preacher, Walisongo, who at the same time also the architect of religious and pesantren institution. ${ }^{16}$ The persuasive way of disseminating Islam has been practiced by the nine saints (Walisongo) especially with regard to the Hinduism and Buddhism as religious culture that existed in Javanese society before the coming of Islam. The model of Islam that had been preached and disseminated by them was and is a cultural Islam, which tolerates local cultures.

One of the examples is the prohibition of slaughtering cow in Kudus Central Java initiated by Sunan Kudus, and still practiced until now. The reason for doing so is because cow was believed by Hinduism especially who lived in Kudus region at that time as a sacred animal. Before the coming of Islam, Kudus was one of the Hindu centre. In the meantime cow is permissible to be consumed according to Islamic teaching. The preservation of prohibiting cow slaughtering perhaps difficult to be found in other Muslim communities outside Kudus, because they do not have the same background and experience as Sunan Kudus and his descendants had. In the context of Kudus, Kyai Asnawi (1861-1959), though he studied for a long time in Middle East, he did not lose his Javanese identity.

An example indicates Asnawi's preservation of the local culture is his refutation to the Dutch colonial government when its representative, Van der Plas, in 1927 offered him a penghulu, a religious position, in Kudus regency. During the colonial time pengbulu is a prestigious position for ulamâ' who held proper Islamic knowledge. The prestige is not only because of the salaries, but also of the authority in the Muslim community. ${ }^{17}$ The reason for refuting that request is due to Asnawi's consideration that had he accepted it, the mission of da'wab would be compromised. The duty of enjoining the good and prohibiting the bad in accordance to Islamic teaching and local culture would be no longer genuine, had he been a part of foreign and colonial agency. ${ }^{18}$

Meanwhile the teaching materials in pesantren represent the ideal aim because they are a combination between law and mysticism that tolerate also the local

${ }^{16}$ See Abdurrahman's analysis on the preservation of local culture by the pesantren community Abdurrahman Mas ud (2004), op.cit., Yogyakarta: LKiS, p. 10-11.

17 More detail about Penghulu, see, Muhamad Hisyam (2001), Canght between Three Fires: The Javanese Pengulu under the Dutch Colonid Administration 1882-1942, Jakarta: INIS.

${ }^{18}$ Compare, Abdurrahman Mas'ud (2002), "K.H.R Asnawi Kudus (1861-1959) A Typical Itinerant Kyai, in Ibya Ulumudin, vol 4., Number 1 July 2002, p. 24-25 
religiosity. ${ }^{19}$ The plurality of opinion in the figh literature that is supported also by the philosophy of thinking in the Islamic legal theory, ushul al-figh, makes the pesantren tradition adjustable with the local community and tradition. ${ }^{20}$ Even though there is a different status between high tradition, i.e. the religious texts, and low tradition, i.e. local wisdom, in praxis, there is no contradiction; on the contrary both of them are complementary.

Some pesantren teachers use a combinatory approach in transforming religious knowledge to their students. An example can also be found in the personality of Asnawi. In his works entitled Mu'tagad Seket, he emphasizes the importance of attitude to be carried out by Muslim. According to Mu'taqad Seket, Muslim should i) perform worship in earnestness, ii) accomplish the wujubat, required tasks, iii) stay away from the mabrumat, forbidden, and give entire credence to Sunnism as laid out by Abu Ash'ari or Maturidi in theology.21

The model of development within its tradition also strengthens the nature of pesantren's education. It is a model, which is presumably influenced by the Javanese tradition. A quotation from Babad Djaka Tingkir can be used as an indicator of such influence:

Dhandhanggula duk semona ing tanab Djawi

pun wus Islam sedaya tan wonten barenjul sagung ingkang para ajar

Myang mewasi, geguntung magujud (sic)cantrik

Wus kathab nandhang iman

Myang sogata sewa resi-resi

Wus liniron, kang para pukaha

Pra pandhita gedbe-gedbe

Pra ulama linubung

Para sabid para mungabid

Mupti lawan sulakba

Khukama gung-agung

${ }^{19}$ Abdurrahman Wahid (1988), "Principles of Pesantren Education" in Manfred Oepen and Wolfgang Karcher, The Impact of Pesantren in Education and Community Development in Indonesia, Jakarta: P3M, p. 197.

${ }^{20}$ Van Bruinessen enumerates the percent of religious materials that is taught in the pesantren, namely $20 \%$ jurisprudence, $17 \%$ theology, $12 \%$ Arabic grammar, $8 \%$ hadits, $7 \%$ mysticism, $6 \%$ ethics, $5 \%$ collection of prayer and $6 \%$ song and praise to the Prophet Muhammad. See, Lukens-Bull (1997), "A Peaceful Jihad: Javanese Islamic Education and Religious Identity Construction", Ph.D. thesis, ASU, p. 68 69; van Bruinessen (1990), "Kitab Kuning: Books in Arabic Script Used in the Pesantren Milieu" in Bijdragen tot de Taal Land en Volkenkunde 146, p. 229.

${ }^{21}$ Asnawi (no date), Ma'tagad Seket, Surabaya, p. 2. 
(Now at the time in Java's land all had become Muslim there were none who do resist all the mountain hermits (ajar) the ascetics and acolytes the devotees and disciples many converted to the faith and the royal Buddhis and Saivite monks the Hindu priests were exchanged for fuqaha (lawyers) great and mighty pundits excellent leamed ulama mystic zahud and mujahid mufti and sulaha great and mighty khukama) ${ }^{22}$

\section{Pesantren vis a vis Givic Values}

Civic values as mentioned in the previous paragraph are among others 1) freedom and tolerance, ii) democracy, and iii) gender equality. The pesantren tradition, which is based on the combination between Islamic doctrines and local values, is adaptable to such values. The previous paragraph mentioned also that many scholars have conducted research on pesantren. Some of them made anthropological studies using the popular method of participant observation; some others taught foreign language, especially English, while others were interested in learning deeper about Islam. These direct encounters with "outsider" have been an invaluable experience for santris (pesantren's students), which has nurtured awareness and appreciation of differences and diversities. It is not surprising therefore, that pesantren in Indonesia have produced broad minded and tolerant alumni. ${ }^{23}$

Another unique character of pesantrens, which has enabled them to produce tolerant and pluralistic people, is their balance in teaching Islamic legal aspects (figh) and the spirituality (sufism). This approach can be traced back to derive from the nine saints (Walisongo) who spread Islam on the island of Java peacefully. The spiritual dimension is what probably missing in some pesantrens that are "radical" who prefer to stand in a binary position: right/wrong, halal/haram, me/the other et cetera. As a result, they produce people with an exclusionary stance who see the

${ }^{2}$ Babad Djake Tingeir XIII, 19-20, in Nancy K Florida (1995), Writing tbe Past, Inscribing the Future, Duke University Press, p. 320. See also Mas'ud (2004), op. cit., p. 58-59.

${ }^{23}$ Scholars and community leaders such as Abdurrahman Wahid, Nurcholis Madjid, Muslim Abdurrahman are examples of pesantren alumni. 
world as black and white and who lack the beauty and inner meaning of the religion: peace tolerance, respect, love and care for others, and other esoteric and humanitarian traits.

As an example of such feature can be seen in most pesantren in the south of central Java, ${ }^{24}$ without considering that other pesantren located outside this region is not good enough for the example. This institution preserves the local tradition which supports the teaching of high culture, i.e., Islamic teaching. One can easily find the combination between Islamic rituals and teaching and traditional music such gendbing Banymasan as a musical religious song practiced by the Muslim in villages before praying together, shalât al-jamâ ah.

In the region of Banyumas, Central Java, for instance, in the pesantren of Ahmad Thohari, ${ }^{25}$ one can find the existing musical art called gendbing Banyumasan that is preserved by the pesantren community. The praise to the Prophet Muhammad in the form of shalawatan is also composed in the Javanese language with some nice modification that shows the mutual relationship between Islamic teaching in pesantren and local culture. Moreover, in the region in south Java whose tradition are among others exemplified in the song, such as Dbandbang Gula, Sinom, typical Javanese songs, Islamic teachings are written and sung in that form. One of the examples is about the way to understand the Qur'an as the basis source of Islam. The song is the following:

Jroning Quran, nggoné rasa yekti

Nanging jalma tan padba uninga

Kajaba iman tudbube.

Nora kena den awur...

ing satemah nora pinangib...

mundbak kata lanju'an

Temah sasar susur...

yen sira hayun waskitba.

sampurnakna badanira puniki...

sira-anggeguruba ${ }^{26}$

${ }^{24}$ South part of the Central Java meant in this paper is the district of Kebumen and Cilacap. Surveys on pesantren in these areas, such as Lirap in Kebumen and Ihyâ Ulumudin in Cilacap have shown the tolerative habits of both pesantren communities to the local culture. The model of javanese fasting (puasa mutib) for instance, is one of the Javanese model that is practiced by many santries in both pesantren.

${ }^{25} \mathrm{He}$ is a kyai and prolific author on Indonesian literature. Among his works are Ronggeng Dukuh Parak, Senym Karjamin, Bekisar Merab and many others.

26 See Mohamad Ardani (1988), Mistik Islam Kejawen Raden Ngabebi Ranggawarsita: Studi terbadap Serat Wirid Hidayat Jati, Jakarta: UI Press, p. 78. 
The Qur'an has wonderful teachings, yet, not all human being can appropriately understand its message, and only with the help of belief someone can comprehend it. It is forbidden to interpret the message without knowledge, it will mislead the understanding. When you have a sufficient knowledge, go on to understand the message also with the help of sufficient teachers..)

Pesantren has been practicing democratic elements in its method of learning. The sources of Islamic studies in the pesantren, especially in the domain of Islamic legal theory, entail element of freedom of choices, using one opinion and neglecting others without any psychological hindrance. The figh books used in the pesantren teach how to preserve one opinion, moreover the opinions that are product of legal reasoning, jjithatd. In the framework of Islamic legal theory a pattem is taken noticed of, namely the result of legal reasoning, jitibâd, cannot be detracted by another product of legal reasoning, al-ijtibâd la yungadu bi l-ijtibâd. ${ }^{27}$ On the other hand, in the domain of figh literature there are four popular school of thoughts, madzhab, in the pesantren. By choosing one madzbab it does not necessarily mean eliminating others. Legal opinions written in books such as al-Majmâ Syarb al-Mubajjab, Fath al-IVabhâb, I ânat al-Tbalibin which are Syafi ian oriented perpetuate the tolerance on different opinions. The phrase wa-gilla, "and it is said" is numerous in those books which indicate the tolerant nature of different opinions among scholars in different school of thoughts.

It is not exaggerative when someone says that the tolerance is a part of the pesantren's culture. At the same time, when it is confronted to Indonesian context which is plural and multi ethnic, the pesantren tradition with its educational system will ready to come forth. It is also important to be noticed that different religion is also perceived by the pesantren community as a given, sunnatullab. Therefore, the - various and different religious praxis is respected by pesantren because every single community has his right to do so. The pesantren also believes that only with the respect and tolerance the diversity of community can be reached.

Tolerance is a starting point of openness and dialogue. In this sense, dialogue means open communication between groups, be they are the same or different. The dialogue is directed not to make the difference become handicap for together, on the contrary, it is directed to exchange experiences among those who have differences. Dialogue can be executed when there is a similar status, similar right and duty, between those who have differences, and last but not least without claiming that one is superior and the other is inferior. When someone believes that his own conviction is true he should at the same time realizes that it cannot be the "whole"

${ }^{27}$ This maxim is very popular in the literature of Islamic legal theory, See for example, Jalâluddîn

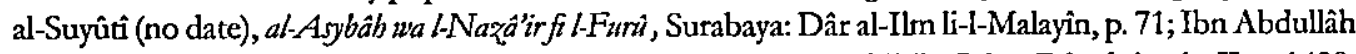
al-Juwainî (no date), al-Burbân fí Ushâlal-Fiqhb, (ed.), Abd al- Azîm al-Dîb, Cairo: Dâr al-Ansâr, II, p. 1480. 
truth, the "absolute," un-limited truth. He should learn more about teality and the ultimate meaning of life from the other. Relating to openness of the pesantren, this institution will play a significant role in creating milieu of dialogue among different communities and even among different religions.

Dialogue in general, and especially inter-religious dialogue, then, is the way forward to an increasingly complete, but never fully complete, grasp of reality, of the ultimate meaning of life and how to live accordingly. Thus, inter-religious dialogue must be - and in fact is becoming - the new religious heart at the core of the emerging pluralistic view. The core spirit of dialogue is fundamentally democratic, egalitarian, person-in-community and context oriented. For dialogue can occur only among free, reflective persons. If there is no freedom there will be no dialogue. Further, dialogue can take place only among equals. Also, dialogue happens only in community and in the environment of the wider common context.

Another aspect of civic values is about gender issue, namely discourse on equal right between man and women. It is undeniable that pesantren is mostly tagged by women activist as an institution that has no gender sensitivity. In other words, pesantren is often comprehended as being gender bias especially in using and interpreting religious texts. This image is to some extent true when its entry point is the usage of some books which are discriminatory. The relation of husband and wife, for instance, is explained in some Islamic literature in such a way that creates an image that husband is hegemonic. On the other hand, when looking at the holistic literature used by pesantren such image is not fully true. This is due to the fact that many opinions given by scholars on particular school of thought that legitimise the equal right between man and women.

An example can be found in the case of women who take responsibility for leader of prayer, imâm. Although the majority of scholars prohibited this task, there are still opinion given by al-Muzannî and Abû Tsaur (d. 240/854) which allow that kind of imâm. This opinion is also strengthened by al-Tabarî when the prayer is not a daily prayer but only a prayer during the night of ramadhan with an additional condition, namely, there is no man who can takes the responsibility of being imam. ${ }^{28}$ Another case is the possibility of women of being a judge. Although the majority of scholars in figh prohibited it, there is still an opinion given by Abû Hanifah (d. 150) which states that women could be elected as judge not only for the positive law, but also for penal or criminal law without any restriction. This opinion is also supported by ibn Jarir al-Tabari. (d. 310). ${ }^{29}$

Gender equality is also an important issue in Indonesian context. One should

${ }^{28}$ See al-San ânî, Subul al-Salâm, vol. I, 28-29.

${ }^{22}$ Ibn Rusyd (no date), Bidâyat al-Mujtabid wa-Nibâyat al-Mugtasid, Beirut: Dât al-Fikr, , vol II, p. 
not interpret that a specific religion places women in the second position under the superiority of man. The fact is on the contrary, namely that every religion puts the equality between both. In the case of Islam, the understanding of some verses of the Qur'an is sometimes understood as a legitimacy of the man superiority. This model of understanding has been criticized by numerous Indonesian Muslim thinkers and has been advocated to the proportional understanding which respects the equality of man and women's rights.

\section{Concluding Remarks}

Discussing pesantren tradition and its educational system reaches a holistic view on its concept as an "ideal" Islamic education. This ideal education tries to make appropriate function of its three elements, namely, cognitive, affective and psychomotoric. Secular concept of education is to some extent unconsciously neglects one elements by focusing on others. At the same time pesantren as a subculture entails local values that strengthen the so-called civic values. The civic values which are among others freedom and tolerance, democracy and gender equality are an ideal goal of an educational system that should be executed by the government policy. In a multi cultural context of Indonesian society, education should be directed to give to live awareness of the plurality in community. Hence, pesantren tradition plays an important rule in contributing the positive tradition to the search of an ideal type of Islamic education in the framework of establishing the Indonesian system of education.

\section{BIBLIOGRAPHY}

Abdurrahman Mas'ud (2002), “K.H.R. Asnawi Kudus (1861-1959): A Typical Itinerant Kyai", in Ibya Ulumudin, vol. 4, number 1.

. (2004), Intelektual Pesantren: Perhelatan Agama dan Tradisi,Yogyakarta: LKiS.

Abdurrahman Wahid (1988), "Principles of Pesantren Education, dalam Manfred

Oepen dan Wolfgang Karcher, The Impact of Pesantren in Education and Communily Development in Indonesia, Jakarta: P3M.

Azyumardi Azra (2002), Paradigma Baru Pendidikan Nasional: Rekonstruksi dan

Demokratisasi, Jakarta: Penerbit Kompas.

Bruinessen, Martin van (1990), "Kitab Kuning: Books in Arabic Script Used in the

Pesantren Milieu" in Bijdragen tot de Taal Land en Volkenkunde.

Dawam Raharjo (1985), Pergulatan Dunia Pesantren, Jakarta: LP3ES.

Departemen Agama (2002), Statistik Pondok Pesantren 2002, Direktorat Pendidikan

Keagamaan dan Pondok Pesantren. 
Florida, Nancy K (1995), Writing the Past, Inscribing the Future, Duke University Press. Goleman, Daniel (1995), Kecerdasan Emosional, trslt., T. Hermaya, Jakarta: Gramedia Pustaka Utama.

Ibn Abdullâh al-Juwainî (n.d), al-Burbân fí Usbâl al-Figh, (ed.), Abd al- Azîm al-Dîb. Cairo: Dâr al-Ansâr.

Ibn Rusyd (n.d), Bidâyat al-Mujtabid wa-Nibâyat al-Muqtasid, Beirut: Dâr al-Fîkr. Jatâluddîn al-Suyûtî (n.d), al-Asybâb wa l-Naqẩie fí l-Furâ, Surabaya: Dâr al-Ilm li-lMalayîn.

Kueng, Hans (2000), Global Etbics, Muenchen: Herder Verlag.

Lukens-Bull (1997), "A Peaceful Jihad: Javanese Islamic Education and Religious Identity Construction", Ph.D. thesis, ASU.

Mohamad Ardani (1988), Mistik Islam Kejawen Raden Ngabebi Ranggawarsita: Studi terhadap Serat Wirid Hidajat Jati, Jakarta: UI Press.

Muhamad Hisyam (2001), Caught between Three Fires: The Javanese Pengulu under the Dutch Colonial Administration 1882-1942, Jakarta: INIS.

Müller, Alois (1996), Die Pesantren auf Java, Frankfurt: am-Main.

Steenbrink, Karel (1994), Pesantren, Madrasab dan Sekolab:Pendidikan Islan dalam Kurun Moderen, Jakarta: LP3ES.

Sya'rani Ahmadi (1986), al-Farâ'id al-Saniyyah, Kudus: Menara Kudus.

van den Berg, L.W.C. (1886), "Heet Mohammedaansche Godsdientonderwijs op Java en Madoera en de Daarbij Gebruikte Arabische Boeken", in Tijdschrift voor Indische Taal, Land- en Volkenkunde 31.

Zamakhsyari Dhofier (1982), Tradisi Pesantren, Jakarta: LP3ES. (1999), "The Pesantren Tradition: The Role of the Kyai in the Maintenance of Traditional Islam in Java Temple", in Arizona State University Program for South East Asian Studies Monograph.

Zarnûbî (n.d), Ta lim al-Muta allim, Semarang: Pustaka Alawiyah. 